\title{
CAN THE USE OF A SPECIFICALLY DESIGNED AMINOGLYCOSIDE PRESCRIPTION SHEET REDUCE RISK IN NEONATAL PRACTICE?
}

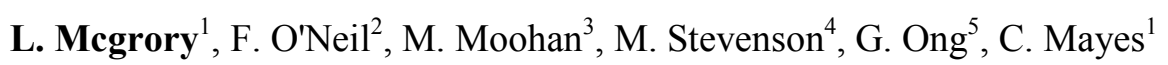 \\ ${ }^{1}$ Regional Neonatal Unit, Royal Jubilee Maternity Hospital, Belfast, ${ }^{2}$ Department of Pharmacy, Ulster \\ Hospital, Dundonald, ${ }^{3}$ Department of Pharmacy, Royal Victoria Hospital, ${ }^{4}$ Centre for Public Health, \\ Queen's University, ${ }^{5}$ Department of Microbiology, Royal Victoria Hospital, Belfast, UK
}

Background: Aminoglycosides are commonly prescribed in Neonatal Care but are frequently associated with error. An NPSA directive recommends using a care bundle to reduce error in neonatal Gentamicin prescribing. This includes crossing out boxes on a standard medication prescription and administration record. This can cause confusion and in addition there are no specific areas for documentation of monitoring.

Methods: A specifically designed aminoglycoside prescribing sheet was introduced in a level 3 neonatal unit in 2008. Audits looking at appropriate dosing, drug level timing and response to abnormal levels were undertaken before and after introduction. The frequency of reported error prior to, and following introduction, was monitored through incident reporting.

Results: Table 1 demonstrates a reduction in aminoglycoside errors of $80 \%$ following the introduction of the new prescribing sheet. This compares to a fall of $35 \%$ for non- aminoglycoside errors. We compared the rates of fall using a test of differential reduction (Fishers exact test, 2 sided $p$ value), which approached significance $(\mathrm{p}=0.077)$.

\begin{tabular}{|l|l|l|l|l|l|l||}
\hline & $\begin{array}{l}\text { Nov 07-April } \\
08\end{array}$ & $\begin{array}{l}\text { May 08-Oct } \\
08\end{array}$ & $\begin{array}{l}\text { Nov 08- April } \\
09\end{array}$ & $\begin{array}{l}\text { May 09-Oct } \\
09\end{array}$ & $\begin{array}{l}\text { Nov 09- April } \\
10\end{array}$ & $\begin{array}{l}\text { May 10-Oct } \\
10\end{array}$ \\
\hline $\begin{array}{l}\text { Total no. of } \\
\text { reported non - } \\
\text { aminoglycoside } \\
\text { drug errors }\end{array}$ & 27 & 10 & 16 & 24 & 15 \\
\hline $\begin{array}{l}\text { Total no. of } \\
\text { aminoglycoside } \\
\text { errors } \\
\text { prescription, } \\
\text { administration })\end{array}$ & $6(2,4)$ & $2(1,1)$ & $1(0,1)$ & $1(0,1)$ & $1(1,0)$ & $1(0,1)$ \\
\hline
\end{tabular}

[Table 1: Reported drug errors before and after the]

Conclusion: An aminoglycoside prescribing sheet should be considered as part of a care bundle designed to reduce risk. 